\section{Analysing the role of information technology towards sustainable cities living}

Analysing the role of information technology

2037

\author{
Universita degli Studi di Napoli Parthenope, Napoli, Italy
}

\begin{abstract}
Purpose - The purpose of this study is to identify the pathway that leads to cities to proceeding towards urban sustainability.

Design/methodology/approach - This study intends to propose a theoretical analysis on the city as sustainable community that drives urban development adopting a smart vision for urban growth.

Findings - Cities as sustainable urban communities develop smartness as a vision for change understanding and developing the potential offered by information technology reinforcing the community by shaping collaborative governance.

Research limitations/implications - Cities using information technology as a source for urban sustainability develop smartness to evolve as smart communities following a managerial and organizational view towards sustainability as a source for continuous innovation and change within urban ecosystem.

Originality/value - Cities identify a sustainability-oriented and community-driven pathway as a vision for continuous change that helps to improve urban competitiveness, innovation and democracy ensuring high quality of life by strengthening the potential offered by technology-enabled and human-centred smartness.
\end{abstract}

Keywords Information technology, Smart city, Urban sustainability, Smart community, Smart governance

Paper type Conceptual paper

\section{Introduction}

Cities of the future should achieve urban sustainability as a source for urban value creation and development. Cities of tomorrow should be sustainable, knowledge- and innovationoriented and technology-enabled communities. Within knowledge-based societies, cities of tomorrow contribute to promoting sustainable, social and economic growth in developing knowledge, human and technological sources. Designing the city as a community supports urban value creation by developing human capital, innovation and knowledge development. Cities as sustainable urban ecosystems (Newman and Jennings, 2008) should promote urban economic growth and development, improving the quality of life by using information and communication technologies (ICTs) and following a smart city view to successfully support processes of innovation and knowledge creation over time (Nam and Pardo, 2011a, 2011b; Dameri, 2013; Czarniawska, 2002; Paskaleva, 2011; Deakin, 2014; Leydesdorff and Deakin, 2011).

(C) Mauro Romanelli. Published by Emerald Publishing Limited. This article is published under the Creative Commons Attribution (CC BY 4.0) licence. Anyone may reproduce, distribute, translate and create derivative works of this article (for both commercial and non-commercial purposes), subject to full attribution to the original publication and authors. The full terms of this licence may be seen at http://creativecommons.org/licences/by/4.0/legalcode
Received 30 July 2019 Revised 12 January 2020 Accepted 18February 2020 
$\mathrm{K}$

49,7

The sustainability of cities relies on urban communities acquiring intellectual capital, fostering knowledge-based processes and infrastructures and developing sources for innovation (Eger, 2005; Deakin, 2014). To become smart and sustainable communities, cities should identify the smart approach as a vision that enables the city as a knowledge-based and technology-enabled engine to design and implement urban development and sustainability of urban ecosystems (Lindskog, 2004; Gómez-Baggethun and Barton, 2013; Leydesdorff and Deakin, 2011).

Technology enables urban smartness as a source for city's sustainability that displays in improving the quality of urban life. Promoting smart urban development helps sustainability by driving an urban development view focused on social and environmental issues as being relevant at local and city level and avoiding the embedding of corporate interests within urban management (Evans et al., 2019). Developing smart cities agendas and applications contributes to advancing cities towards a sustainability-oriented future (Yigitcanlar and Kamruzzaman, 2018). Thereby, a smart city is considered as a system that helps to improve the quality of life (Silva et al., 2018) based on global-local urban strategy influenced by global drivers and local contingencies (Dameri et al., 2019). ICTs enable smart and sustainable cities to achieve the improvement of urban quality of life as the main goal of an urban development strategy (Al-Nasrawi et al., 2015). Smart city solutions contribute to enhancing urban competitiveness, sustainability, liveability and city's innovation capabilities (Ricciardi and Za, 2014). Information technology supports growth within society and contributes to driving sustainable human development (Gouvea et al., 2018). Today, cities are rethinking their strategy to plan urban sustainability (Yigitcanlar and Teriman, 2015) highly related to local urban specificity (Angelidou et al., 2017). Smart city solutions contribute to advancing urban sustainable development and improving the quality of life as the main goal for cities of the future that evolve towards smart and sustainable growth relying on efficient use of resources (Bătăgan, 2011). Smartness helps cities rediscover community development by empowering citizens for change (Stratigeia, 2012) and to proceed towards urban sustainability because only a sustainable city is also a smart city (Ahvenniemi et al., 2017). Identifying a pathway for urban sustainability relies on city's intelligence and collaborative processes that involve citizens, companies, research and public authorities (Komninos, 2014). As sustainable urban spaces and smart communities, cities strengthen collaboration between local government, businesses education, research centres and people to drive change. In particular, the city's organisational intelligence is the main source that enables the city to develop smartness in the urban ecosystem (Deakin and Al Waer, 2011).

Understanding how cities can design and implement the future relies on considering the relationship between smartness, community and sustainability as concepts driving cities towards social and economic growth and urban value creation. Today, designing and developing a pathway for urban sustainability is emerging as a key task cities should perform to better promote urban growth, support innovation and the urban knowledge economy and ensure high quality of life. While many studies focus on urban development in terms of local smartness and sustainability, few studies tend to elucidate and provide an integrated picture of the relationships between urban sustainability, smartness and community development as drivers that contribute to improving the quality of life within urban ecosystems. The aim of this study is to identify the pathway that leads cities to proceed towards urban sustainability. Cities should identify a pathway for urban sustainability by developing a smart city vision, sustaining smart community development and encouraging smart collaborative governance and cooperation. The main contribution of this study is to identify the trajectories of development that drive cities to evolve as 
communities following a smart approach to develop sustainability as a source for continuous innovation and change. The article is structured as follows. After the introduction and methodological section, in Section 2 and in Section 3, a picture about how cities as communities become smart and sustainable is provided. In Section 4, it is explained how to drive cities towards urban sustainability by identifying smartness as an urban vision for social and economic growth, rethinking cities as smart communities and paying attention to reinventing the modes of urban governance. Finally, the discussion and conclusions are presented in Sections 5 and 6.

Analysing the role of information technology

2039

\section{Methodological section}

The study intends to propose a theoretical analysis of the city as smart and sustainable community that drives urban development. The research is exploratory and tends to identify a conceptual framework that elucidates the trajectories that help cities to rethink the urban development as relying on promoting a community vision in the design, planning and implementation of a smart city strategy. The study offers a theoretical study and relies on a review of contributions that refer to understanding the concept of sustainable city, smart city and smart community as drivers of the city as an urban sustainable community. Focusing on smart community and governance concepts helps to reconstruct the city as a community that is evolving towards the future, moving from techno-centric view to a human-centred and collaborative strategy where technology is a means to support organisational, policy and community vision of urban growth. Smartness, sustainability, governance and community are the key words and values that help cities to rethink the urban development by improving services and promoting innovation within the urban context and ecosystem. Referred journal articles and book chapters were selected from Google Scholar as the main web source and database. Sources are grouped to elucidate how the community concept is emerging in the smart city and smart community discourse. In particular, re-visiting smart city concept under the lens of a human-centred vision leads to considering several contributions that focus on the relationship between smartness and the community approach. The reported articles were selected concerning cities as communities going sustainable and smart, promoting a human-centred view smart and sustainable city, rethinking cities as smart communities and reinventing the urban governance. The selected contributions are analysed and interpreted in a narrative synthesis to accommodate the differences between questions, research design and the context. They will also contribute to elucidating new perspectives and advancing theoretical frameworks on emerging issues (Denyer and Tranfield, 2006; Dixon-Woods et al., 2004).

\section{Towards cities as communities going sustainable and smart}

Cities are economic and social systems in the urban space (Clark, 2004). Cities enable people to work towards driving the sustainable development of urban communities, fostering social, economic and cultural growth in the urban landscape. Cities play a proactive role in shaping urban sustainability and enhancing the quality of life for people living in urban environments. According to Bibri and Krogstie (2017), urban sustainability refers to cities that strategically contribute to achieving a balance between environmental protection, economic development, regeneration and social equity within urban society. Cities should develop a pathway for urban sustainability to improve the quality of life. Sustainable cities develop a change-oriented strategy to keep continuity in urban activities and policies. Urban sustainability refers to resilient cities capable of maintaining continuity whilst situations are changing and reflecting on the role of the city (Nijkamp and Perrels, 1994). A sustainable city should be able to reform the way in which the city interacts with the global economy 
$\mathrm{K}$

49,7

2040

and environment (Haughton, 1997). Sustainability should be an attribute of smart cities that develop, meeting the needs of the future and compromising the well-being of future generations (Perez-Ortiz et al., 2017). Sustainable cities support economic and social, inclusive and responsible growth (Deakin et al., 2012). Sustainable cities contribute to delivering economic, social and cultural development to all inhabitants (Murphy, 2000); improving community-oriented and people-centred services and building communities by encouraging urban governance; and strengthening environmental management as drivers that help ensure better quality of life (United Nations, 2013). Cities as communities and learning systems contribute to promoting social interaction and stimulating creativity by improving the wealth of people within the community (Camagni, 1996). Cities are meeting places and spaces for learning and education opportunities, driving change and innovation (Evans et al., 2005). Cities help the urban community to support sustainable development (Satterthwaite, 1997), driving change by achieving long-term and successful issues (Czarniawska, 2002). Cities ensure efficient service delivery and infrastructures improving quality of life and well-being of its citizens, ensuring economic growth and employment opportunities (Dhingra and Chattopadhyay, 2016).

Cities as sustainable communities help intelligent urban policy-making (Innes and Booher, 2000), thus strengthening social capital (Bridger and Luloff, 2001) and empowering citizens to actively contribute to achieve urban value creation and sustainability (Haapio, 2012).

Following the goal, 11 of UN 2030 Agenda for sustainable development cities should be sustainable, inclusive, safe and resilient urban communities. According to the European Commission (2017) cities are the main actors able to develop meaningful policy-making addressing the urban challenges they face. According to the Bristol agreement, sustainable communities meet the needs of existing and future residents, contribute to a high quality of life, are safe and inclusive, are well planned and offer equal opportunities, refer to places where people will live and work. Urban sustainability relies on promoting smart growth that relies on cities as smart communities promoting innovation processes (European Commission, 2012), driving urban growth, strengthening knowledge transfer and encouraging multi-level governance and stakeholder involvement (European Commission, 2017).

Cities aiming to rethink urban planning select a sustainability-oriented and smart strategy to improve quality of life strengthening user participation and multi-actor decision-making (Yigitcanlar and Teriman, 2015; Komninos et al., 2019). Sustainable cities develop and implement urban development integrating social, economic and environmental issues, preserving the ecosystem and improving the quality of life (Yigitcanlar et al., 2015), promoting sustainable urban development improving and extending the wealth of people within a community (Trindade et al., 2017). In the information age, cities are developing the potential of technology to drive urban sustainability and ensure quality of life becoming smart communities as a better place to live and work (Lara et al., 2016), empowering citizens as co-designers, co-innovators and co-producers of services and knowledge (Granier and Kudo, 2016). Sustainable cities develop infrastructures for high urban quality of life, social and economic exchanges and inclusion and accountable city government (Castells, 2000). Cities should identify a pathway for sustainability in relation to implementation stages of smart sustainable city design (Huovila et al., 2019), promoting a smart city vision meeting the needs of people and supporting knowledge and innovation economy (Angelidou, 2015). 


\section{Driving cities towards urban sustainability}

Sustainable cities and communities should promote and shape a smart city vision, developing smart urban communities and using technology to identify models of governance by redefining the relationship between local city government and citizenry and developing urban collaborative forms of governance.
Analysing the role of information technology

\subsection{Promoting a human-centred-community smart city view}

According to Yigitcanlar (2017), a smart city extensively uses ICTs to provide and ensure high quality of life to its citizens. According to OECD (2019), smart cities contribute to sustaining citizen well-being and delivering inclusive and efficient urban services relying on a multi-stakeholder process. According to the European Commission, a smart city is a place where traditional networks and services are made more efficient with the use of digital and telecommunication technologies for the benefit of its inhabitants and business.

Whilst in the past, as digital cities used technologies to create public spaces for people living and visiting cities (Ishida, 2002), smart cities develop human and social capital sources, integrating technological, organisational and social infrastructures and capabilities (Albino et al., 2015), promoting sustainable economic growth and governance for ensuring high quality of life (Caragliu et al., 2011). Cities should adopt a smart vision for rethinking city design to modernise urban services and infrastructures using ICTs. A smart city concept helps to discuss the use of technology as applied to urban life (Giffinger et al., 2007). Technology, land, organisation, institutions, citizens and policy drive smart city as policy and managerial and innovation (Nam and Pardo, 2011a, 2011b; Dameri, 2013).

Smart city is enabled by the use of technologies to improve competitiveness and ensure a sustainable future by combining networks of people, businesses, technologies, infrastructures, consumption, energy and spaces. Cities becoming smart support innovation for competitiveness of local communities and ensure high urban quality of life through providing efficient services and preserving the environment (Appio et al., 2019). Smart cities contribute to improving operational and managerial efficiency, quality of life relying on innovative technology-enabled infrastructures (Nam and Pardo, 2011a, 2011b). Cities are developing and implementing a smart view to become more sustainable cities (Deakin et al., 2012). Developing a smart approach leads to innovation in urban areas and helps support smart cities as a knowledge base of the regional innovation systems (Leydesdorff and Deakin, 2011) to improve urban environment, economy, mobility, living, governance and education by developing the potential of information technology (Giffinger et al., 2007).

Sustainability as a central paradigm in the context of urban development plays a relevant role in virtue of smart city's trend. Sustaining a smart city helps community development by empowering citizens for change (Stratigeia, 2012). According to Yigitcanlar et al. (2019a, 2019b), urban smartness relies on embracing a human-centred approach, whereas the technology is a means to drive cities to support sustainable urban development. According to Lee and Lee (2014), smart city services should focus on citizen-centricity to improve urban quality of life. Smart cities as communities achieve long-term issues using information technology to promote and extend high quality of life in urban environments, strengthening the connections between productivity, economic growth and human capital, enhancing service systems and capabilities in an urban network and ecosystem (Albino et al., 2015; Shapiro, 2006). 
$\mathrm{K}$

49,7

2042

Cities should promote smartness as a human-centred vision to urban development. Smart city as a community tends to promote the well-being of citizens working for increasingly becoming a better place for work, play and live (Lara et al., 2016). The use of technology enables the development of collaborative intelligence (Saba et al., 2018). Technology should serve for driving cities to design a smart city strategy for building people-centric and urban, collective intelligence in learning, processing and thinking (Xu and Geng, 2019), focusing on people, governance, collaboration and innovation co-creation for fostering social inclusion and enhancing the well-being of citizens (Trencher, 2019).

Following a knowledge-based view, cities of the future as knowledge-oriented communities (Kunzmann, 2014) support collective learning processes and reinforce knowledge and intellectual infrastructures (Knight, 1995) to drive urban competitiveness (Begg, 1999) and support social and economic growth, addressing social and environmental issues (Leon, 2018) as a vision and source to ensure high quality of life and help cities to proceed towards sustainability. Constructing smart and sustainable cities enables key priorities, long-term urban planning and integrated knowledge management processes (Chang et al., 2018). Smart city as urban strategy relates to use of technology to enable knowledge platforms for collective sharing and value creation (Dameri and Ricciardi, 2015). A smart city view contributes to creating intellectual capital relying on linking technology and knowledge. Following an intellectual capital view, smart city as an urban strategy contributes to improving quality of life and strengthening communication between people and public administration by reinforcing relationships and social capital (Dameri et al., 2014). A smart strategy helps develop a virtuous sustainable pathway for innovation and wise use of resources (Cocchia, 2014), and improving services for citizens and urban quality of life (Bifulco et al., 2016). Smart and sustainable cities use ICTs to identify new ways to address urban development preserving capabilities for meeting the needs of future generations (Höjer and Wangel, 2015).

Smart cities encourage user-driven, open and collaborative innovation (Schaffers et al., 2011). In particular, urban sustainability relies on smart cities that use technology for enhancing the social infrastructure pillar concerning people and their relationships (Silva et al., 2018). Building the smart city means using technology for improving the quality of economic and social life within urban communities (Lazariou and Roscia, 2012). Truly smart and sustainable cities are moving from techno-centricity to a post-anthropocentric approach (Yigitcanlar et al., 2019a). Promoting community, technology and policy as drivers of urban sustainable development helps cities to adopt and implement a smart strategy (Yigitcanlar et al., 2019b). Promoting smartness as human-centred vision to urban development within cities helps to drive cities towards a sustainable future (Yigitcanlar and Kamruzzaman, 2018).

Following a smart vision contributes better to improving quality of life and rediscovering the community approach and development (Gil-Garcia et al., 2015; Allwinkle and Cruickshank, 2011), by involving local stakeholders in planning urban transformation of the city (Lara et al., 2016), and promoting collective and collaborative urban innovation and interaction involving all the urban players (Andreani et al., 2019).

\subsection{Rethinking cities as smart urban communities}

Cities of the future as smart communities in the knowledge-based economies play a central role for improving the urban competitiveness, development and quality of life (Eger, 2009). Chourabi et al. (2012) refer to smart community in terms of cities managing ICTs to better interact with citizens using data, information and knowledge for problem solving. ICTs drive communities to become smart communities (Moser, 2001), understanding how 
technology serves for transforming the community's economy and society, promoting job growth and improving the quality of life (Eger, 2005). Information technology is a critical element to drive cities as smart communities that support innovation sources for knowledge creation and diffusion. Cities should be smart, sustainable and healthy communities as the best places to live and work (Eger, 1997). According to Lindskog (2004) a smart community relies on the alliance between local government institutions, education, business and healthcare institutions and people working together and using technology to promote significant and positive transformation of the urban community. A smart community relies

Analysing the role of information technology

2043 on developing collaborative processes of all urban stakeholders as a way for driving urban sustainable development and promoting the city of the future (Eger, 2005).

As smart and sustainable communities, cities of tomorrow should encourage partnerships and dialogue between private and public actors to ensure high quality of life driving sustainable urban growth in shaping the urban and local development (Eger, 2005). Smart urban communities rely on collaboration as a vision for urban growth and help develop collaborative models of governance that enhance citizen engagement (Snow et al., 2016).

Cities as smart communities and collaborative spaces rediscover the opportunities offered by strategic cooperation between government, industry, university and civil society to achieve urban sustainability by enabling cooperative processes within urban ecosystem (Lombardi et al., 2012). According to Yigitcanlar et al. (2019a, 2019b), making the city smart helps the community to be smart. Cities embracing technology to become smart contribute to community meaning and building develop participatory governance and civil society's engagement as a source for driving urban transformation (Lara et al., 2016), rediscovering a community approach to developing innovation (Allwinckle and Cruickshank, 2011). Promoting cities as smart urban communities helps identify a change orientation for driving urban development and improving the quality of lfie (Deakin, 2011). Smart community contributes to supporting citizen satisfaction and well-being (Silva et al., 2018) and relies on fostering a mutually-constructive interaction between the urban players (citizens, researchers and designers, and stakeholders) for collaborative innovation (Andreani et al., 2019).

Developing cities as urban and smart communities relies on empowerment or shared governance that includes all the urban stakeholders to actively participate in policy options about their city (Eger, 2005). Cities becoming smart evolve as urban communities that adopt a human-centred approach developing democratic, cooperative and collaborative processes to foster urban innovation (Andreani et al., 2019). Promoting smartness helps to ensure high quality of life by reinforcing the urban community meaning and integration that relies on collaborative decision-making processes (Macke et al., 2018).

Smart communities contribute to promoting job growth, economic development and improving the quality of life (Eger, 1997). Smart communities rely on proactive role of citizens. Promoting human-centred smart cities helps urban communities to develop cooperative and collaborative processes that foster urban innovation. Urban development models refer to community approach relying on consensus building among all the stakeholders involved in the process of urban transformation (Bayulken and Huisingh, 2015).

\subsection{Cities reinventing urban governing}

Cities as smart communities reinvent urban governing. According to Eger (1997), smart community relies on engaging the body politic to reinvent governing because governance shapes economic development and helps cities to change and be inclusive (Allam and 
$\mathrm{K}$

49,7

2044

Newman, 2018). Urban complex challenges require smarter governance mechanisms coherently with a social and technological approach to understanding and facing the city's problems (Razaghi and Finger, 2018). Smart growth implies smart governance and relies on cities developing spaces for dialogue, meaning building by designing platforms that enable citizen participation and involvement in policy issues and support social inclusion (Anttiroiko, 2016). Technology-enabled solutions enable citizen participation in city governance and contribute to fostering community engagement (Chourabi et al., 2012). Smart city governance refers to sustaining collaboration through the use of ICTs for more open governance processes (Meijer and Bolivar, 2015). ICTs enable value-driven models of governance to transform organisational and institutional arrangements (Ferro et al., 2013). Sustaining smart governance helps to both define better urban policies and strengthen the local cooperative knowledge potential, structuring the cooperation between government and other private and public organisations. Sustaining smart city governance helps the quality of the urban environment by influencing the nature of problem-domain and strengthens the local cooperative knowledge potential (Meijer, 2016). ICTs help to involve and engage citizens to enable and design smart initiatives and projects for ensuring better services and build satisfying policies that contribute to facing and solving public problems for the collective community (Bolívar, 2015). Smart growth implies smart governance and relies on cities that support citizen engagement to strengthen social inclusion (Anttiroiko, 2016). Smart city initiatives contribute to building an urban community to engage citizens more effectively (Paskaleva, 2009). Smart cities contribute to redefining the relationship between people and city government leading city governments are using technology for modelling sustainable forms of governance adapting to situational and specific urban context (Meijer and Thaens, 2018).

Smart city governance relies on multi-actor involvement and collaborative models of governance to support innovation, liveability and competitiveness issues (Broccardo et al., 2019). City governments drive the relationship management with citizens coherently with an evolving view moving from e-administration where citizens are interactive users of personalized services, transitioning through e-governance where citizens contribute to policy agenda, towards a learning city whereas citizens learn how to learn (Michel, 2005).

Cities becoming smart develop democracy and participatory governance (Deakin, 2014). Promoting urban collaborative governance relies on developing urban data management platforms to design new models of urban smart governance and address urban contemporary challenges (Barns, 2018). In particular, stressing participatory citizen engagement helps focus on a citizen centricity in terms of democratic, city decision-making processes and social innovation issues (Castelnovo et al., 2016). Participatory platforms contribute to driving local development and shaping the city (Anttiroiko, 2016), to strengthening the communication and knowledge exchange citizen-to-citizen and community networks coherently with a user democracy perspective (Anttiroiko et al., 2014). ICT-based participation platforms help municipal authorities to explore new ways to provide transparent and democratic communication, empowering citizens in the urban policy process (Gün et al., 2019).

\section{Discussion}

Cities drive urban, social and economic development and select a pathway for sustainability following a smart vision relying on using information technology as a source for urban and human-centred change. Cities as smart communities understand the potential of information technology to support collaboration between public and private organisations, to improve 
urban competitiveness, innovation and ensure the quality of life. Technological advancements are leading cities as engines of innovation to promoting urban and regional economic development, and social growth by enabling the citizens as full members of local communities, strengthening citizen involvement and participation, and sustaining a smart city approach for developing services platforms.

Cities of tomorrow should select a strategic agenda by involving different stakeholders and designing digital and technological infrastructures for building collaborative forms of governance. Cities should evolve as smart communities, sustaining democratic and participatory cooperation and interaction between private and public organisations. As smart and sustainable communities, cities acquire and develop human capital and knowledge sources to develop organisational and individual learning to promote value creation. Following a smart approach, cities drive urban, social and economic development, and they select a pathway for sustainability. The main contribution of this study was to identify the trajectories of development that drive cities to evolve as smart communities to develop sustainability as source for continuous innovation and change.

As shown in the Figure 1, a pathway has been identified that helps to understand how cities rethink, plan and design a pathway towards the sustainable city.

There are several ways to drive cities towards sustainability. Smartness is a source and vision for change and driving urban communities towards sustainability. Smart city vision is changing and evolving over time. Smart cities are only a smart urban place in the sense that they develop information technology as a support for efficient services managing traditional forms of urban governance and following a techno-centric view. In this way, cities are constructing a community-oriented urban development process by reinventing the urban governance and understanding the potential offered by information technology to better build cooperative processes and alliances for urban transformation. In this way, developing a smart vision helps community-oriented cities to rethink the community meaning. Smartness helps cities and all urban stakeholders to rediscover a human-centred view for urban growth and sustainability. As smart communities, cities identify a pathway for community development and engagement whereas governing the city is the main framework to define the relationships between people and city government. Sustainable cities promote smartness as a source to rediscover the importance of a community and use information technology for transforming both organisational frameworks for innovation and governance, rethinking and strengthening a human-centred view to urban ecosystem growth. Sustainable cities plan the city of the future as learning organisation continuously oriented to change, innovation, knowledge and value creation processes. It is necessary to promote the conditions for transition from governing the city to reinventing governing for enhancing smart and collaborative governance by using the potential offered by information technology to support policies that drive cities to develop not only services platforms but to also develop competencies for innovation and knowledge creation. Information technology helps cities to become smart human-centred communities of people and to rediscover the importance of dialogue, cooperation and values sharing as sources for creating social, economic and public value within urban ecosystems. Cities following a smart strategy use technology for becoming sustainable communities that enable knowledge

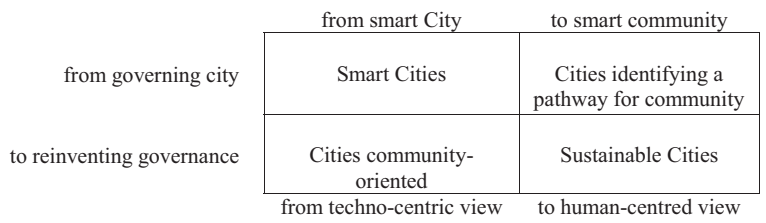

Analysing the role of information technology

\section{5 \\ $\longrightarrow$}


$\mathrm{K}$

49,7

creation and development. Smart and sustainable cities should evolve from merely ensuring and providing efficient and effective services to developing technology-enabled and knowledge-driven sources for urban innovation and growth as technology-enabled and knowledge-driven strategic design.

\section{Conclusions}

In developing a smart approach, cities drive social and economic growth for designing the city as a community which involves public and private organisations in urban planning for collaborative governance and innovation development, constructing a community in the urban area. As urban communities designing long-terms policies for change and continuous innovation, sustainable cities should promote trust-based relationships fostering citizen participation in policy processes and smart collaborative governance, seeking a dialogue with citizenry. Sustainable cities of the future rely on developing a smart approach for enabling urban social and public value creation and development over time, viewing the city as a community that encourages cooperation and collaboration between city government, people, business, research and education centres by promoting social and economic innovation, providing services, and creating knowledge for continuous learning to ensure high quality of life. As smart and sustainable communities, cities should support knowledge creation and people (creativity, diversity and education), develop smart governance and design smart policies for driving an enduring urban development, re-inventing the future and re-adapting to changes. Cooperation between people, businesses and organisations living in the city helps rethink the design of the city as a sustainable community. Designing cities as sustainable communities relies on driving the transition from a smart city to a smart urban community, promoting knowledge sources for developing learning processes and innovation.

In this study, there are theoretical, managerial, organisational and social implications. Sustainable and smart cities should evolve as communities and strengthen the organisational dimension in planning urban smart and sustainable growth. Rethinking the city of the future asks for managerial capabilities and vision in addressing strategic and organisational choices. Cities planning a smart and sustainable pathway for the future become organisation-oriented and change-driven communities that continuously contribute to value creation processes achieving long-terms goals in terms of economic and social growth and sustainability. Designing sustainable cities is a long-term and change process that involves all the stakeholders of urban society and relies on developing smart and sustainable city vision as a multi-stakeholder and participative process. For developing smart and sustainable communities, cities need to understand the potential of information technology to create and use knowledge to promote urban innovation, value creation and learning opportunities.

Future research perspectives imply a need to investigate how cities are using technology in urban sustainable strategy and planning relying both on a smart vision and also embracing a community-oriented view as a future pathway for urban, inclusive and socially responsible and human-driven growth.

\section{References}

Ahvenniemi, H., Huovila, A., Pinto-Seppä, I. and Airaksinen, M. (2017), "What are the differences between sustainable and smart cities?", Cities, Vol. 60, pp. 234-245.

Albino, V., Berardi, U. and Dangelico, R.M. (2015), "Smart cities: definitions, dimensions, performance, and initiatives”, Journal of Urban Technology, Vol. 22 No. 1, pp. 3-21. 
Allam, Z. and Newman, P. (2018), "Redefining the smart city: culture, metabolism and governance", Smart Cities, Vol. 1 No. 1, pp. 4-25.

Allwinkle, S. and Cruickshank, P. (2011), "Creating smart-er cities: an overview”, Journal of Urban Technology, Vol. 18 No. 2, pp. 1-16.

Al-Nasrawi, S., Adams, C. and El-Zaart, A. (2015), "A conceptual multidimensional model for assessing smart sustainable cities", Journal of Information Systems and Technology Management, Vol. 12 No. 3, pp. 541-558.

Andreani, S., Kalchschmidt, M., Pinto, R. and Sayegh, A. (2019), "Reframing technologically enhanced urban scenarios: a design research model towards human centered smart cities", Technological Forecasting and Social Change, Vol. 142, pp. 15-25.

Angelidou, M. (2015), "Smart cities: a conjuncture of four forces”, Cities, Vol. 47, pp. 95-106.

Angelidou, M., Psaltoglou, A., Komninos, N., Kakderi, C., Tsarchopoulos, P. and Panori, A. (2017), "Enhancing sustainable urban development through smart city applications", Journal of Science and Technology Policy Management, Vol. 9 No. 2, pp. 146-169.

Anttiroiko, A.-V. (2016), "City-as-a-platform: the rise of participatory innovation platforms in Finnish cities", Sustainability, Vol. 8 No. 9, pp. 1-31, 922.

Anttiroiko, A.-V., Valkam, P. and Bailey, S.J. (2014), "Smart cities in the new service economy: building platforms for smart services", AI and Society, Vol. 29 No. 3, pp. 323-334.

Appio, F.P., Lima, M. and Paroutis, S. (2019), "Understanding smart cities: innovation ecosystems, technological advancements and societal challenges", Technological Forecasting and Social Change, Vol. 142, pp. 1-13.

Barns, S. (2018), "Smart cities and urban data platforms: designing interfaces for smart governance", City, Culture and Society, Vol. 12, pp. 5-12.

Bătăgan, L. (2011), "Smart cities and sustainability models", Informatica Economică, Vol. 15 No. 3, pp. 80-87.

Bayulken, B. and Huisingh, D. (2015), "A literature review of historical trends and emerging theoretical approaches for developing sustainable cities (part 1)", Journal of Cleaner Production, Vol. 109, pp. 11-24.

Begg, I. (1999), “Cities and competitiveness”, Urban Studies, Vol. 36 Nos 5/6, pp. 795-809.

Bibri, S.E. and Krogstie, J. (2017), "Smart sustainable cities of the future: an extensive interdisciplinary literature review”, Sustainable Cities and Society, Vol. 31, pp. 183-212.

Bifulco, F., Tregua, M., Amitrano, C. and D'Auria, A. (2016), "ICT and sustainability in smart cities management”, International Journal of Public Sector Management, Vol. 29 No. 2, pp. 132-147.

Bolívar, M.P.R. (2015), "Smart cities: big cities, complex governance?", in Bolívar, M.P.R. (Ed.), Transforming City Governments for Successful Smart Cities, Springer, Cham, pp. 1-7.

Bridger, J.C. and Luloff, A.E. (2001), "Building the sustainable community: is social capital the answer?”, Sociological Inquiry, Vol. 71 No. 4, pp. 458-472.

Broccardo, L., Culasso, F. and Mauro, S.G. (2019), "Smart city governance: exploring the institutional work of multiple actors towards collaboration", International Journal of Public Sector Management, Vol. 32 No. 4, pp. 367-387.

Camagni, R. (1996), Economia e Pianificazione Della Città Sostenibile, IlMulino, Bologna.

Caragliu, A., Del Bo, C. and Nijkamp, P. (2011), "Smart cities in Europe", Journal of Urban Technology, Vol. 18 No. 2, pp. 65-82.

Castells, M. (2000), "Urban sustainability in the information age”, City, Vol. 4 No. 1, pp. 118-122.

Castelnovo, W., Misuraca, G. and Savoldelli, A. (2016), "Smart cities governance: the need for a holistic approach to assessing urban participatory policy making", Social Science Computer Review, Vol. 34 No. 6, pp. 724-739.
Analysing the role of information technology

2047 
$\mathrm{K}$

49,7

Chang, D.L., Sabatini-Marques, J., da Costa, E.M., Selig, P.M. and Yigitcanlar, T. (2018), "Knowledgebased, smart and sustainable cities: a provocation for a conceptual framework", Journal of Open Innovation: Technology, Market, and Complexity, Vol. 4 No. 1, pp. 1-17.

Chourabi, H., Gil-Garcia, J.R., Pardo, T.A., Nam, T., Mellouli, S., Scholl, H.J., Walker, S. and Nahon, K. (2012), "Understanding smart cities: an integrative framework", 45th HI International Conference on System Sciences, IEEE, pp. 2289-2297.

Clark, D. (2004), Urban World/Global City, Routledge, London and New York, NY.

Cocchia, A. (2014), "Smart and digital city: a systematic literature review", in Dameri, R.P. and Rosentahl-Sabroux, C. (Eds), Smart City. How to Create Public and Economic Value with High Technology in Urban Space, Progress in IS, Springer, Cham, pp. 13-43.

Czarniawska, B. (2002), "Remembering while forgetting: the role of automorphism in city management in Warsaw", Public Administration Review, Vol. 62 No. 2, pp. 163-173.

Dameri, R. (2013), "Searching for smart city definition: a comprehensive proposal", International Journal of Computers and Technology, Vol. 11 No. 5, pp. 2544-2551.

Dameri, R.P. and Ricciardi, F. (2015), "Smart city intellectual capital: an emerging view of territorial systems innovation management", Journal of Intellectual Capital, Vol. 16 No. 4, pp. 860-887.

Dameri, R., Ricciardi, F. and D'Auria, B. (2014), "Knowledge and intellectual capital in smart city", The Proceedings of the 15th European Conference on Knowledge Management, pp. 250-257.

Dameri, R.P., Benevolo, C., Veglianti, E. and Li, Y. (2019), "Understanding smart cities as a glocal strategy: a comparison between Italy and China”, Technological Forecasting and Social Change, Vol. 142, pp. 26-41.

Deakin, M. (2011), "The embedded intelligence of smart cities", Intelligent Buildings International, Vol. 3 No. 3, pp. 189-197.

Deakin, M. (2014), "Smart cities: state-of-the-art and governance challenge", Triple Helix, Vol. 1 No. 1, pp. 1-16.

Deakin, M. and Al Waer, H. (2011), "From intelligent to smart cities", Intelligent Buildings International, Vol. 3 No. 3, pp. 133-139.

Deakin, M., Hirst, P., Hummerstone, E., Webb, S., Karlsson, A.-K., Blin, A.-S., Duff, M. and Jordanou, M. (2012), JESSICA for Smart and Sustainable Cities, European Investment Bank, Mazars LLP, London.

Denyer, D. and Tranfield, D. (2006), "Using qualitative research synthesis to build an actionable knowledge base", Management Decision, Vol. 44 No. 2, pp. 213-227.

Dhingra, M. and Chattopadhyay, S. (2016), "Advancing smartness of traditional settlements-case analysis of Indian and Arab old cities", International Journal of Sustainable Built Environment, Vol. 5 No. 2, pp. 549-563.

Dixon-Woods, M., Agarwall, S., Young, B., Jones, D. and Sutton, A. (2004), Integrative Approaches to Qualitative and Quantitative Evidence, Health Development Agency, London, available at: www.hda.nhs.uk

Eger, J.M. (1997), “Cities of the future. The role of smart and sustainable communities”, pp. 114-121.

Eger, J.M. (2005), "Smart communities, universities, and globalization: educating the workforce for tomorrow's economy”, Metropolitan Universities, Vol. 16 No. 4, pp. $28-38$.

Eger, J.M. (2009), "Smart growth, smart cities, and the crisis at the pump. a worldwide phenomenon, IWays journal of E-Government policy and regulation", I-WAYS, Digest of Electronic Commerce Policy and Regulation, Vol. 32 No. 1, pp. 47-53.

European Commission (2012), "Smart cities and communities - European Innovation Partnership, C (2012) 4701 final”, Brussels, 10 July.

European Commission (2017), "Report from the Commission to the Council on the Urban Agenda for the EU, COM(2017) 657 final, 20 December". 
Evans, B., Joas, S., Sundback, S. and Theobald, K. (2005), Governing Sustainable Cities, Earthscan, London.

Evans, J., Karvonen, A., Luque-Ayala, A., Martin, C., McCormick, K., Raven, R. and Palgan, Y.V. (2019), "Smart and sustainable cities? Pipedreams, practicalities and possibilities", Local Environment, Vol. 24 No. 7, pp. 557-564.

Ferro, E., Caroleo, B., Leo, M., Osella, M. and Pautasso, E. (2013), "The role of ICT in smart cities governance", Proceedings of 13th International Conference for E-democracy and Open Government. Donau-Universität Krems, pp. 133-145.

Giffinger, R., Fertner, C., Kramar, H., Kalasek, R., Pichler-Milanović, N. and Meijers, E. (2007), "Smart cities: ranking of European medium-sized cities", Centre of Regional Science (SRF), Vienna University of Technology, Vienna, available at: www.smart-cities.eu/download/smart_ cities_final_report.pdf

Gil-Garcia, J.R., Pardo, T.A. and Nam, T. (2015), "What makes a city smart? Identifying core components and proposing an integrative and comprehensive conceptualization", Information Polity, Vol. 20 No. 1, pp. 61-87.

Gouvea, R., Kapelianis, D. and Kassicieh, S. (2018), "Assessing the nexus of sustainability and information and communications technology", Technological Forecasting and Social Change, Vol. 130, pp. 39-44.

Gómez-Baggethun, E. and Barton, D.N. (2013), "Classifying and valuing ecosystem service for urban planning”, Ecological Economics, Vol. 86, pp. 235-245.

Granier, B. and Kudo, H. (2016), "How are citizens involved in smart cities? Analysing citizen participation in Japanese 'smart communities", Information Polity, Vol. 21 No. 1, pp. 61-76.

Gün, A., Demir, Y. and Pak, B. (2019), "Urban design empowerment through ICT-based platforms in Europe”, International Journal of Urban Sciences, pp. 1-27.

Haapio, A. (2012), "Towards sustainable urban communities", Environmental Impact Assessment Review, Vol. 32 No. 1, pp. 165-169.

Haughton, G. (1997), "Developing sustainable urban development models", Cities, Vol. 14 No. 4, pp. 189-195.

Höjer, M. and Wangel, J. (2015), "Smart sustainable cities: definition and challenges", in Hilty, L.M. and Aebischer, B. (Eds), ICT Innovations for Sustainability, Springer, Cham, pp. 333-349.

Huovila, A., Bosch, P. and Airaksinen, M. (2019), "Comparative analysis of standardized indicators for smart sustainable cities: what indicators and standards to use and when?", Cities, Vol. 89, pp. 141-153.

Innes, J.E. and Booher, D.E. (2000), "Indicators for sustainable communities: a strategy building on complexity theory and distributed intelligence", Planning Theory and Practice, Vol. 1 No. 2, pp. 173-186.

Ishida, T. (2002), "Digital city Kyoto", Communications of the ACM, Vol. 45 No. 7, pp. 76-81.

Knight, R.V. (1995), "Knowledge-based development: policy and planning implications for cities", Urban Studies, Vol. 32 No. 2, pp. 225-260.

Komninos, N. (2014), "Introduction: the age of intelligent cities", in Komninos, N. (Ed.), The Age of Intelligent Cities. Smart Environments and Innovation-for-All Strategies, Routledge, London, pp. 1-9.

Komninos, N., Kakderi, C., Panori, A. and Tsarchopoulos, P. (2019), "Smart city planning from an evolutionary perspective”, Journal of Urban Technology, Vol. 26 No. 2, pp. 3-20.

Kunzmann, K.R. (2014), "Smart cities: a new paradigm of urban development", Crios, Vol. 4 No. 1, pp. 9-20.

Lara, A.P., Da Costa, E.M., Furlan, T.Z. and Yigitcanlar, T. (2016), "Smartness that matters: towards a comprehensive and Human-Centred characterisation of smart cities", Journal of Open Innovation: Technology, Market and Complexity, Vol. 2 No. 2, pp. 1-13.
Analysing the role of information technology

2049 
$\mathrm{K}$

49,7

2050

Lazariou, G.C. and Roscia, M. (2012), "Definition methodology for the smart cities model", Energy, Vol. 47 No. 1, pp. 326-332.

Lee, J. and Lee, H. (2014), "Developing and validating a citizen-centric typology for smart city services", Government Information Quarterly, Vol. 31, pp. s93-s105.

Leon, R.D. (2018), "Sustainable knowledge based organizations. definition and characteristics", Environmental Engineering and Management Journal, Vol. 17 No. 6, pp. 1425-1437.

Leydesdorff, L. and Deakin, M. (2011), "The triple-helix model of smart cities: a neo-evolutionary perspective", Journal of Urban Technology, Vol. 18 No. 2, pp. 53-63.

Lindskog, H. (2004), "Smart communities initiatives", Proceedings of the 3rd ISOneWorld Conference, Vol. 16.

Lombardi, P., Giordano, S., Farouh, H. and Wael, Y. (2012), "Modelling the smart city performance", Innovation: The European Journal of Social Science Research, Vol. 25 No. 2, pp. 137-149.

Macke, J., Casagrande, R.M., Sarate, J.A. and Silva, K.A. (2018), "Smart city and quality of life: citizens' perception in a Brazilian case study", Journal of Cleaner Production, Vol. 182, pp. 717-726.

Meijer, A., et al. (2016), "Smart city governance: a local emergent perspective", in Gil-Garcia, J.R. (Ed.), Smarter as the New Urban Agenda: A Comprehensive View of the 21st Century City, Public Administration and Information Technology, Springer, Cham, Vol. 11, pp. 73-85.

Meijer, A. and Bolivar, M.P.R. (2015), "Governing the smart city: a review of the literature on smart urban governance", International Review of Administrative Sciences, Vol. 82 No. 2, pp. 392-408.

Meijer, A. and Thaens, M. (2018), "Urban technological innovation: developing and testing a sociotechnical framework for studying smart city projects", Urban Affairs Review, Vol. 54 No. 2 , pp. 363-387.

Michel, H. (2005), "e-Administration, e-Government, e-Governance and the learning city: a typology of citizenship management using ICTs", The Electronic Journal of e-Government, Vol. 3 No. 4, pp. 213-218.

Moser, M.A. (2001), "What is smart about the smart communities movement”, EJournal, Vol. 10 No. 11 (1), pp. 1-11.

Murphy, P. (2000), “Urban governance for more sustainable cities”, European Environment, Vol. 10 No. 5, pp. 239-246.

Nam, T. and Pardo, T.A. (2011a), "Smart city as urban innovation with dimensions of technology, people and institutions", Proceedings of the 5th International Conference on Theory and Practice of Electronic Governance, ACM, pp. 185-194.

Nam, T. and Pardo, T.A. (2011b), "Conceptualizing smart city with dimensions of technology, people and institutions", Proceedings of the 12th Annual International Digital Government Research Conference: Digital Government Innovation in Challenging Times, ACM, pp. 282-291.

Newman, P. and Jennings, J. (2008), Cities as Sustainable Ecosystems. Principles and Practices, Island Press, Washington, DC.

Nijkamp, P. and Perrels, A. (1994), Sustainable Cities in Europe, Earthscan, London.

OECD (2019), "1st OECD roundtable on smart cities and inclusive growth", 9 July, CC2, OECD.

Paskaleva, K.A. (2009), "Enabling the smart city: the progress of city e-governance in Europe", International Journal of Innovation and Regional Development, Vol. 1 No. 4, pp. 405-422.

Paskaleva, K.A. (2011), "The smart city: a nexus for open innovation?", Intelligent Buildings International, Vol. 3 No. 3, pp. 153-171.

Perez-Ortiz, M., Bennett, D.R. and Pérez-Bustamante, D. (Eds) (2017), "Preface", Sustainable Smart Cities. Creating Spaces for Technological, Social and Business Development, Springer, Cham, pp. 9-12. 
Razaghi, M. and Finger, M. (2018), "Smart governance for smart cities", Proceedings of the IEEE, Vol. 106 No. 4, pp. 680-689.

Ricciardi, F. and Za, S. (2014), "Smart city research as an interdisciplinary crossroads: a challenge for management and organization studies", in Mola, L., Pennarola, F. and Za, S. (Eds), From Information to Smart Society: Environment, Politics and Economics. Lecture Notes in Information Systems and Organisation, Springer International Publishing, Switzerland, pp. 163-171.

Saba, M., Saba, P.B. and Harfouche, A. (2018), "Hidden facets of IT projects are revealed only after deployment. the case of French agricultural cooperatives", Information Technology and People, Vol. 31 No. 1, pp. 239-255.

Satterthwaite, D. (1997), "Sustainable cities or cities that contribute to sustainable development?", Urban Studies, Vol. 34 No. 10, pp. 1667-1691.

Schaffers, H., Komninos, N., Pallot, M., Trousse, B., Nilsson, M., Oliveira, A., et al. (2011), "Smart cities and the future internet: towards cooperation frameworks for open innovation”, in Domingue, J. (Ed.), The Future Internet Assembly, Springer, Berlin, Heidelberg, pp. 431-446.

Shapiro, J.M. (2006), "Smart cities: quality of life, productivity and the growth. effects of human capital", Review of Economics and Statistics, Vol. 88 No. 2, pp. 324-335.

Silva, B.N., Khan, M. and Han, K. (2018), "Towards sustainable smart cities: a review of trends, architectures, components, and open challenges in smart cities", Sustainable Cities and Society, Vol. 38, pp. 697-713.

Snow, C.C., Håkonsson, D.D. and Obel, B. (2016), "A smart city is a collaborative community lessons from smart Aarhus”, California Management Review, Vol. 59 No. 1, pp. 92-108.

Stratigeia, A. (2012), “The concept of 'smart cities”, Towards Community Development? Networks and Communication Studies, Vol. 36 Nos 3/4, pp. 375-388.

Trencher, G. (2019), “Towards the smart city 2.0: empirical evidence of using smartness as a tool for tackling social challenges”, Technological Forecasting and Social Change, Vol. 142, pp. 117-128.

Trindade, E.P., Hinnig, M.P.F., da Costa, E.M., Marques, J.S., Bastos, R.C. and Yigitcanlar, T. (2017), "Sustainable development of smart cities: a systematic review of the literature", Journal of Open Innovation: Technology, Market, and Complexity, Vol. 3 No. 1, pp. 1-14.

United Nations (2013), "World Economic and Social Survey 2013. Sustainable Development Challenges”, Department of Economic and Social Affairs, New York, NY.

$\mathrm{Xu}, \mathrm{H}$. and Geng, X. (2019), "People-Centric service intelligence for smart cities", Smart Cities, Vol. 2 No. 2, pp. 135-152.

Yigitcanlar, T. (2017), "Editorial: smart cities in the making", International Journal of Knowledge-Based Development, Vol. 8 No. 3, pp. 201-205.

Yigitcanlar, T. and Kamruzzaman, M. (2018), "Does smart city policy lead to sustainability of cities?”, Land Use Policy, Vol. 73, pp. 49-58.

Yigitcanlar, T. and Teriman, S. (2015), "Rethinking sustainable urban development: towards an integrated planning and development process”, International Journal of Environmental Science and Technology, Vol. 12 No. 1, pp. 341-352.

Yigitcanlar, T., Dur, F. and Dizdaroglu, D. (2015), “Towards prosperous sustainable cities: a multiscalar urban sustainability approach”, Habitat International, Vol. 45, pp. 36-46.

Yigitcanlar, T., Hoon, H., Kamruzzaman, M., Ioppolo, G. and Sabatini-Marques, J. (2019b), "The making of smart cities: are Songdo, Masdar, Amsterdam, san Francisco and Brisbane the best we could build?”, Land Use Policy, Vol. 88, p. 104187.

Yigitcanlar, T., Kamruzzaman, M., Foth, M., Sabatini-Marques, J., da Costa, E. and Ioppolo, G. (2019a), "Can cities become smart without being sustainable? A systematic review of the literature", Sustainable Cities and Society, Vol. 45, pp. 348-365.
Analysing the role of information technology

2051 
$\mathrm{K}$

49,7

\section{Further reading}

Bristol Accord (2005), "Conclusions of ministerial informal on sustainable communities in Europe”, UK Presidency, Bristol, 6-7 December.

United Nations (2015), "Transforming our world: the 2030 agenda for sustainable development, A/RES/ 70/1”, 25-27 September, New York, NY.

\section{About the author}

Mauro Romanelli is an Assistant Professor in Organisation and Human Resource Management at University of Naples Parthenope, Department of Business and Economics, Italy. The author's research interests are organisational change, sustainability and human resource management within public sector organisations and public administration, organisation, processes and information and communication technologies within parliaments, health care, cities, museums and cultural heritage. The author's teaching activities are organisation theory and design, organisational behaviour and human resource management. Mauro Romanelli can be contacted at: mauro.romanelli@uniparthenope.it

For instructions on how to order reprints of this article, please visit our website: www.emeraldgrouppublishing.com/licensing/reprints.htm Or contact us for further details: permissions@emeraldinsight.com 